\title{
Use of basaltic waste as red ceramic raw material
}

\section{(Uso de resíduo de basalto como matéria-prima para cerâmica vermelha)}

\author{
T. M. Mendes ${ }^{1}$, G. Morales ${ }^{2}$, P. J. Reis ${ }^{3}$ \\ ${ }^{1}$ Dep. Environmental Engineering, UTFPR, Campus Londrina, Londrina, PR \\ ${ }^{2}$ Dep. Civil Construction, UEL/CTU, Londrina, PR; ${ }^{3}$ Lab. Applied Nuclear Physics, UEL, Londrina, PR \\ thiagomendes@utfpr.edu.br,gmorales@uel.br,pjlondrina@yahoo.com.br
}

\begin{abstract}
Nowadays, environmental codes restrict the emission of particulate matters, which result in these residues being collected by plant filters. This basaltic waste came from construction aggregate plants located in the Metropolitan Region of Londrina (State of Paraná, Brazil). Initially, the basaltic waste was submitted to sieving $(<75 \mu \mathrm{m})$ and the powder obtained was characterized in terms of density and particle size distribution. The plasticity of ceramic mass containing $0 \%, 10 \%, 20 \%, 30 \%, 40 \%$ and $50 \%$ of basaltic waste was measured by Atterberg method. The chemical composition of ceramic formulations containing $0 \%$ and $20 \%$ of basaltic waste was determined by X-ray fluorescence. The prismatic samples were molded by extrusion and fired at $850{ }^{\circ} \mathrm{C}$. The specimens were also tested to determine density, water absorption, drying and firing shrinkages, flexural strength, and Young's modulus. Microstructure evaluation was conducted by scanning electron microscopy, X-ray diffraction, and mercury intrusion porosimetry. Basaltic powder has similar physical and chemical characteristics when compared to other raw materials, and contributes to ceramic processing by reducing drying and firing shrinkage. Mechanical performance of mixtures containing basaltic powder is equivalent to mixtures without waste. Microstructural aspects such as pore size distribution were modified by basaltic powder; albite phase related to basaltic powder was identified by X-ray diffraction.
\end{abstract}

Keywords: waste, powder, raw material, red ceramic.

\section{Resumo}

Atualmente, os códigos ambientais restringem a emissão de material particulado, resultando em um resíduo coletado por filtros. Este resíduo basáltico é proveniente de plantas de produção de agregados para construção, situadas na Região Metropolitana de Londrina, PR (Brasil). Inicialmente, o resíduo basáltico foi submetido a peneiramento $(<75$ um) e o pó obtido foi caracterizado em termos de distribuição do tamanho das partículas. A plasticidade de massas cerâmicas contendo 0, 10, 20, 30, 40 e 50\% de resíduo basáltico foi medida pelo método de Atterberg. A composição química de formulações cerâmicas contendo 0 e $20 \%$ de resíduo basáltico foi determinada por meio de fluorescência de raios X. Corpos de prova prismáticos foram moldados por extrusão e queimados a $850{ }^{\circ} \mathrm{C}$, e determinadas a densidade, a absorção de água, as retrações na secagem e na queima, a resistência à tração na flexão e o módulo de Young das amostras. A microestrutura foi avaliada por microscopia eletrônica de varredura, difração de raios X e porosimetria de intrusão de mercúrio. O pó de basalto apresenta características físicas e químicas similares quando comparado às outras matérias-primas, e contribui para o processamento cerâmico pela redução das retrações na secagem e na queima. O desempenho mecânico da mistura contendo pó basáltico é equivalente à mistura sem pó. Aspectos microestruturais, como a distribuição do tamanho dos poros, são modificados pelo pó basáltico; a fase albita relacionada ao pó de basalto foi identificada por meio de difração de raios $X$.

Palavras-chave: resíduo, pó, matéria-prima, cerâmica vermelha.

\section{INTRODUCTION}

Brazilian ceramic industry is a large natural rawmaterial consumer. According to ANICER [1], more than 100 million tons have been processed, increasing the consumption of natural resources and fuel, and causing serious environmental impacts. As a consequence, in order to reduce non-renewable raw material consumption, many industrial wastes have been tested as raw material for ceramic mass formulations such as steel slag powders [2], galvanic solid waste [3], ceramic slurry waste [4], granite [5-10] and marble [11-13] waste powders, and sedimentary rock powders [14, 15]. Results published in [2] show that in red ceramic formulations containing $2 \%$ to $10 \mathrm{wt} \%$ of steel slag waste as raw material, there was a decrease in flexural strength and water absorption when compared to the mixture without waste. Drying shrinkage was constant, but firing shrinkage showed a considerable difference for mixtures containing $10 \mathrm{wt} \%$ of steel slag waste. Results published in [3] indicate that mixtures containing $2 \%$ and $5 \mathrm{wt} \%$ of galvanic slurry waste present higher firing shrinkage. Furthermore, water absorption for formulations containing waste presented higher values than reference one. Flexural strength increased according to waste contents 
for all studied temperatures $\left(850,900\right.$ and $\left.950{ }^{\circ} \mathrm{C}\right)$. Results published in $[14,15]$ mention that mixtures of red ceramic roof tiles containing residues of sedimentary rocks, in amounts of $30 \%$ to $50 \mathrm{wt} \%$, present a decrease in water demand for extrusion processing according to residue content. For samples fired at 800 and $850{ }^{\circ} \mathrm{C}$, mixtures containing sedimentary residue presented similar values of flexural strength when compared to the reference mixture. For firing temperatures of 900 to $1050{ }^{\circ} \mathrm{C}$, mixtures containing residues presented higher flexural strength values than the reference. Vieira et al. [9] also published results where roof tiles samples containing $5 \%$ to $30 \mathrm{wt} \%$ of granite waste show that coarse granite fraction leads to lower water absorption and flexural strength in mixtures containing this mineral waste, when compared to the reference one without residue. According to [10], red ceramic mass containing $10 \%$ to $40 \mathrm{wt} \%$ of granite waste present a linear decrease in plasticity and water demand for extrusion according to granite residue content. In comparison with the reference without residue, water absorption and flexural strength are directly affected by granite waste used; a clear decrease in both properties was noticed in mixtures containing granite waste. Microstructure is also modified by the presence of granite coarse particles, leading to total porosity decrease and change in the pore size distribution. Monteiro et al. [5] published results showing that ceramic roof tiles samples containing $20 \%, 30 \%$ and $40 \mathrm{wt} \%$ of granite waste as raw material present lower drying and firing shrinkage when compared to the reference, without granite waste. No differences were observed for water absorption in relation to granite waste content, but higher flexural strength was noticed for mixtures containing $40 \mathrm{wt} \%$ of granite sawing waste. Albite and anorthite phases in mixtures containing granite sawing waste were identified by X-ray diffraction. According to results published in [6], ceramic bricks and tiles samples containing $20 \%$ to $60 \mathrm{wt} \%$ of granite sawing waste show flexural strength higher in mixtures containing $20 \%$ of granite waste than in mixtures without waste for all firing temperatures studied $\left(800\right.$ to $\left.1000{ }^{\circ} \mathrm{C}\right)$. Acchar et al. [11] published results indicating that mixtures containing $10 \%$ to $50 \mathrm{wt} \%$ of granite and marble sludge as raw material have higher water absorption in relation to sludge content and consequently a decrease in flexural strength, considering samples fired at 950 to $1050{ }^{\circ} \mathrm{C}$. In samples fired at 1100 and $1150{ }^{\circ} \mathrm{C}$, this property presented similar or higher values than the reference mixture without waste. Anorthite phase was identified by X-ray diffraction for samples containing $30 \mathrm{wt} \%$ of reject. As stated in [8], roof tiles ceramic samples containing residues from granite cutting/polishing and silica sand washing indicate a beneficial effect of waste on ceramic body's properties, reducing water absorption and increasing flexural strength for mixtures containing both wastes. Torres et al. [7] published results indicating that porcelain tile samples containing $20 \%$ to $40 \mathrm{wt} \%$ of granite cutting sludge and fired in industrial furnace at $1210{ }^{\circ} \mathrm{C}$ present similar flexural strength values when compared to mixtures without granite cutting residue. Albite phase was also identified by
X-ray diffraction for mixtures containing granite as raw material. Costa et al. [4] used $1 \%$ and $3 \%$ of ceramic slurry waste as raw material for ceramic samples of terracotta; samples fired at $1050{ }^{\circ} \mathrm{C}$ do not present considerable difference of properties such as flexural strength, water absorption or firing shrinkage. Furthermore, suspension's rheological behavior is not affected by slurry waste used.

Today, environmental codes restrict the emission of particulate matters $[16,17]$, which results in these residues being collected by plant filters and being used as an addition to Portland cement $[18,19]$. However, some minerals such as basalt do not have industrial application on a large scale, causing a significant issue of environmental management [20]. Vieira et al. [10] describe alkaline oxides fluxes effects, mainly $\mathrm{Na}_{2} \mathrm{O}, \mathrm{K}_{2} \mathrm{O}, \mathrm{Fe}_{2} \mathrm{O}_{3}, \mathrm{CaO}$ and $\mathrm{MgO}$, which play an important role during firing, reducing the refractory material and promoting liquid phase formation. A number of studies has been developed in order to provide proper destination to such residues such as raw material for Portland cement clinker [21-23] and mineral admixture to cement based compounds [20,24-26]. Therefore, this paper aims to study the use of basaltic filler waste as a raw material for red ceramic formulations.

\section{MATERIALS AND METHODS}

Two types of clay and basaltic powder waste obtained during the crushing process were collected from local industries in the Metropolitan Region of Londrina and used as raw material. These materials were dried at $110^{\circ} \mathrm{C}$ and basaltic powder waste was sieved to 200 mesh $(75 \mu \mathrm{m})$. The particle size distribution of raw materials and basalt real density $\left(2.85 \mathrm{~g} / \mathrm{cm}^{3}\right)$ were measured by sedimentation method and liquid picnometry according to Brazilian standards [27, 28]; sodium hexametaphosphate was applied as dispersing agent. For plasticity characterization, ceramic mixtures containing $0 \%, 10 \%, 20 \%, 30 \%, 40 \%$ and $50 \mathrm{wt} \%$ of basaltic powder were previously mixed in a plastic bag. Reference ceramic mass is composed by $75 \%$ of clay 01 and $25 \%$ of clay 02 . Mixture compositions are presented in Table I. For extrusion molding and firing, two mixtures, reference and $\mathrm{C} 02$ (20\% of basaltic powder), were tested. For red ceramic mixtures containing basaltic waste, published results in [29] for samples unburned and dried at $110{ }^{\circ} \mathrm{C}$ show a considerable decreasing on material's strength for mixtures containing more than $20 \%$ of basaltic as raw material. Considering these formulations, water was added and manually mixed until an extrusion compatible rheological behavior was achieved. Prismatic ceramic bodies $(12.7 \mathrm{~mm} \times 25.4 \mathrm{~mm} \times 104 \mathrm{~mm})$ were molded without vacuum application. Extruded samples were dried at room temperature $\left(25^{\circ} \mathrm{C}\right)$ for $24 \mathrm{~h}$, then at $70{ }^{\circ} \mathrm{C}$ for $12 \mathrm{~h}$ and finally at $110^{\circ} \mathrm{C}$ for $12 \mathrm{~h}$ in the laboratory oven. Firing was conducted at $850{ }^{\circ} \mathrm{C}$ in a laboratory furnace. Firstly, all samples were submitted to the following heating cycle: (i) firing from 25 to $500^{\circ} \mathrm{C}$ at $10^{\circ} \mathrm{C} / \mathrm{min}$, (ii) from 500 to $850{ }^{\circ} \mathrm{C}$ at $2.5^{\circ} \mathrm{C} / \mathrm{min}$, and (iii) at $850^{\circ} \mathrm{C}$ for $180 \mathrm{~min}(3 \mathrm{~h})$. Then, the 
Table I - Mixtures (in wt $\%$ ) of ceramic compositions.

[Tabela I - Misturas (em \% em massa) das composições cerâmicas.]

\begin{tabular}{ccccc}
\hline Mixture & Clay 01 $(\%)$ & Clay 02 $(\%)$ & Basaltic powder $(\%)$ & Water $(\%)$ \\
\hline Reference & 75.0 & 25.0 & 0 & 28.02 \\
C01 & 67.5 & 22.5 & 10 & n.d. \\
C02 & 60.0 & 20.0 & 20 & 26.50 \\
C03 & 52.5 & 17.5 & 30 & n.d. \\
C04 & 45.0 & 15.0 & 40 & n.d. \\
C05 & 37.5 & 12.5 & 50 & n.d. \\
\hline
\end{tabular}

samples were cooled turning off the furnace. Six specimens of all fired mixtures were tested in order to determine the density, linear shrinkage, water absorption and flexural strength.

Water absorption was determined according to standard procedures [30]. Linear shrinkage was measured based on the specimens' length $( \pm 0.01 \mathrm{~mm})$ before and after drying and firing. Flexural strength was measured according to standard procedures [31], and dynamic Young's modulus according to standard procedures [32]. The microstructure of ceramic samples was analyzed using a scanning electron microscope (SEM), Quanta 600 FEI-Philips; carbon coating treatment was employed on sample surface. Pore size distribution was measured by mercury intrusion porosimetry, using a Micrometrics Pore Size (contact angle $=140^{\circ}$ ). Ceramic and basaltic samples were milled and sieved to 200 mesh $(75 \mu \mathrm{m})$; X-ray diffraction (XRD) patterns of pressed powder samples were measured using a Philips MPD1880 and X'pert PRO MPD X-ray diffractometers (Cu-Ka, $40 \mathrm{kV}$, $30 \mathrm{~mA}, 2 \theta=5-90^{\circ}, 0.2 \%$ s). The chemical composition was determined on molten samples by X-ray fluorescence using the P'ANalyticalAxios Advanced X-ray spectrometer.

\section{RESULTS AND DISCUSSION}

Fig. 1 shows particle size distribution curves of raw-

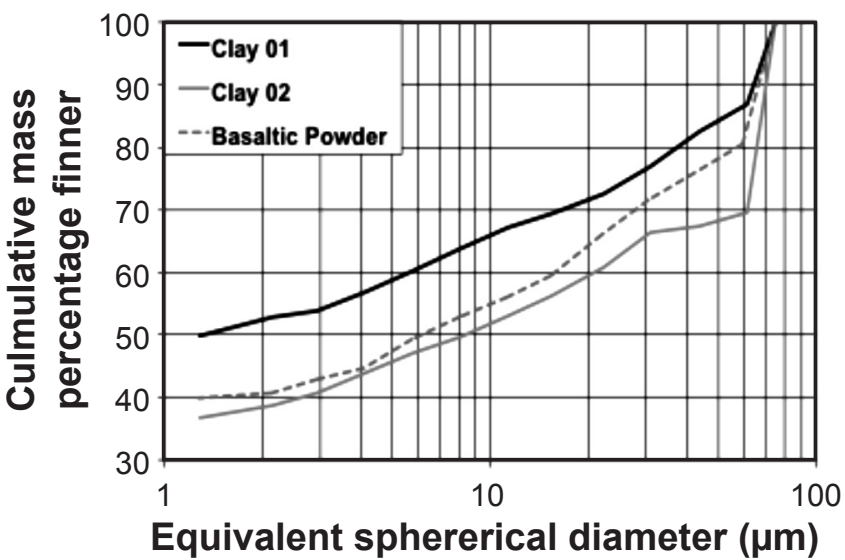

Figure 1: Particle size distribution curves of raw materials.

[Figura 1: Curvas de distribuição de tamanho de partículas das matérias-primas.]

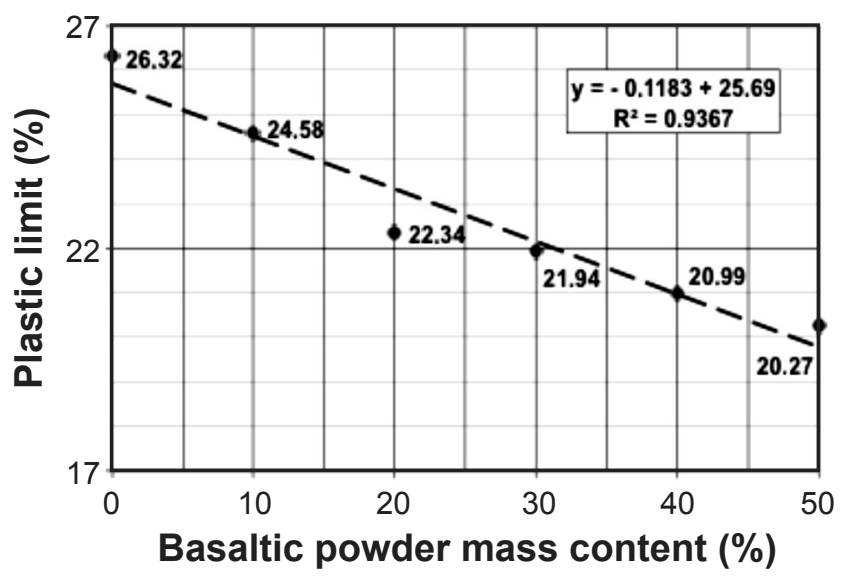

Figure 2: Plasticity of ceramic formulations.

[Figura 2: Plasticidade das formulações cerâmicas.]

materials. $50 \%$ of clay 01 particles and $35 \%$ of clay 02 particles are finer than $2 \mu \mathrm{m}$. Basaltic powder particle size distribution is coarser than clay 01 and finer than clay 02 ; particles finer than $2 \mu \mathrm{m}$ represent $40 \%$ of total mass. Plastic limits of compositions are plotted in Fig. 2; basaltic powder reduces ceramic mass plasticity mainly due to its mineralogical composition, which presents no plastic minerals such as quartz and feldspars and less representative amount of clay minerals such as kaolinite and montmorillonite, both products of feldspars and silicates alteration commonly observed in igneous rocks [33]. A linear relationship is obtained and could be employed in order to determine extrusion water demanding for other mixtures. Vieira et al. [10] presents an acceptable extrusion region considering a plastic limit value between $11 \%$ and $34 \%$.

Ceramic mass containing basaltic powder presents higher contents of total alkaline oxides than the reference mixture, mainly $\mathrm{Na}_{2} \mathrm{O}, \mathrm{K}_{2} \mathrm{O}, \mathrm{Fe}_{2} \mathrm{O}_{3}, \mathrm{CaO}$ and $\mathrm{MgO}$, and similar silica and alumina contents (Table II). Alkaline oxides present on basaltic powder came from basaltic phases, such as albite $\left[\mathrm{Na}\left(\mathrm{AlSi}_{3} \mathrm{O}_{8}\right)\right]$, anorthite $\left[\mathrm{Ca}\left(\mathrm{Al}_{2} \mathrm{Si}_{2} \mathrm{O}_{8}\right)\right]$, labradorite $\left[\mathrm{Ca}, \mathrm{Na}_{(}\left(\mathrm{Al}_{2} \mathrm{SiO}_{3} \mathrm{O}_{8}\right)\right]$, and augite $[(\mathrm{Ca}, \mathrm{Na})$ $\left(\mathrm{Mg}, \mathrm{Fe}^{2+}, \mathrm{Al}, \mathrm{Fe}^{3+}, \mathrm{Ti}\right)(\mathrm{Si}, \mathrm{Al})_{2} \mathrm{O}_{6}$. According to [34], the loss of ignition of basaltic samples is related with the weathering level of materials, mainly the clay minerals, such as kaolinite and montmorillonite resulting from alteration of 
Table II - Chemical composition of basaltic powder, and reference and $\mathrm{C} 02$ mixtures (wt $\%$ ).

[Tabela II - Composição química do pó de basalto e misturas de referência e C02 (\% em massa).]

\begin{tabular}{lccccccccccc}
\hline Mixture & $\mathrm{SiO}_{2}$ & $\mathrm{Al}_{2} \mathrm{O}_{3}$ & $\mathrm{Fe}_{2} \mathrm{O}_{3}$ & $\mathrm{MnO}$ & $\mathrm{MgO}$ & $\mathrm{CaO}$ & $\mathrm{Na}_{2} \mathrm{O}$ & $\mathrm{K}_{2} \mathrm{O}$ & $\mathrm{TiO}_{2}$ & $\mathrm{P}_{2} \mathrm{O}_{5}$ & L.I. \\
\hline Reference & 75.5 & 10.5 & 6.01 & $<0.1$ & 0.59 & 1.38 & 0.23 & 1.10 & 1.28 & 0.10 & 2.66 \\
Basaltic powder & 51.8 & 16.3 & 11.3 & 0.14 & 3.71 & 8.80 & 2.96 & 1.28 & 0.93 & 0.39 & 2.08 \\
$\mathrm{C} 02$ & 71.2 & 11.2 & 7.90 & 0.10 & 1.04 & 1.68 & 0.44 & 1.09 & 1.32 & 0.12 & 3.01 \\
\hline
\end{tabular}

Table III - Physical and mechanical properties of mixtures. [Tabela III - Propriedades físicas e mecânicas das misturas.]

\begin{tabular}{lcc}
\hline Property & Reference & C02 \\
\hline Drying linear shrinkage (\%) & $8.79 \pm 0.22$ & $8.09 \pm 0.21$ \\
Firing linear shrinkage (\%) & $1.38 \pm 0.37$ & $1.19 \pm 0.21$ \\
Density (g/cm ${ }^{3}$ ) & $1.83 \pm 0.02$ & $1.93 \pm 0.05$ \\
Water absorption (\%) & $13.57 \pm 1.04$ & $12.17 \pm 0.31$ \\
Apparent porosity (\%) & $24.82 \pm 1.24$ & $23.52 \pm 0.57$ \\
Flexural strength (MPa) & $7.26 \pm 0.69$ & $7.28 \pm 0.32$ \\
Dynamic Young's modulus (GPa) & $30.12 \pm 3.03$ & $29.51 \pm 0.99$ \\
\hline
\end{tabular}

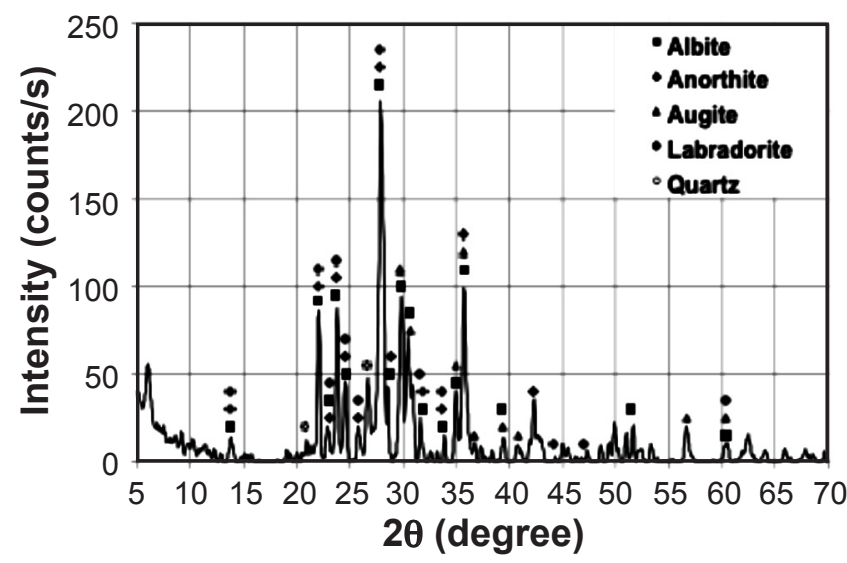

Figure 3: X-ray diffraction pattern of basaltic powder.

[Figura 3: Difratograma de raios $X$ do pó de basalto.]

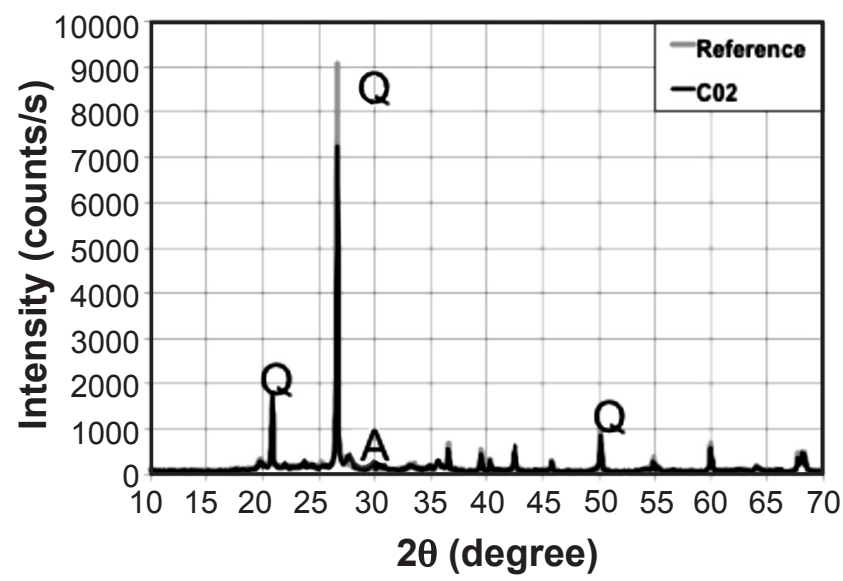

Figure 4: X-ray diffraction patterns of reference and $\mathrm{C} 02$ mixtures: $\mathrm{Q}$ - quartz $\left(\mathrm{SiO}_{2}\right) ; \mathrm{A}$ - albite $\left(\mathrm{NaAlSi}_{3} \mathrm{O}_{8}\right)$.

[Figura 4: Difratogramas de raios $X$ das misturas de referência e C02: $Q$ - quartzo $\left(\mathrm{SiO}_{2}\right) ; \mathrm{A}$ - albita $\left(\mathrm{NaAlSi}_{3} \mathrm{O}_{8}\right)$.]

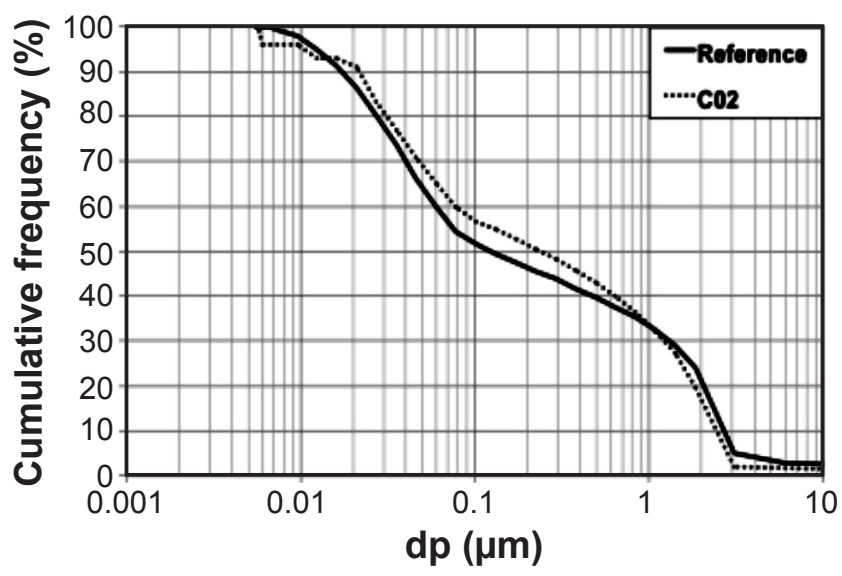

Figure 5: Pore size distribution of reference and $\mathrm{C} 02$ mixtures.

[Figura 5: Distribuição do tamanho dos poros das misturas de referência e C02.]

feldspar and silicates phases presenting in basaltic rocks. Thermogravimetric analysis published in [29] for basaltic filler shows that material present a total mass loss at $900{ }^{\circ} \mathrm{C}$ of about $2 \%$ mainly related with free water, interlamellar water and chemically bonded water of clay minerals. Rosa et al. [35] published results of basaltic filler's thermodilatometric analysis, which show that material is stable until 1000 ${ }^{\circ} \mathrm{C}$; similar result has been published in [29] for sintering temperature.

Mixture C02 has similar drying shrinkage as compared with reference, but both present an excessive value due to the extrusion process without vacuum application (Table III). Similar firing shrinkage values could be verified for both mixtures. Mixture containing basaltic filler is denser than reference mixture due to the basaltic density, reducing the mixture apparent porosity and water absorption (Table III). The mixture's flexural strength and dynamic Young's modulus are similar and no significant differences can be noticed for both mixtures (Table III).

Fig. 3 presents the XRD pattern of basaltic powder, which shows the main phases observed on basaltic rock, such as albite, anorthite, labradorite, augite and quartz. In Fig. 4, the XRD patterns of pressed samples from both reference and ceramic $02(\mathrm{C} 02)$ are presented and a proportional difference in the main peak intensity for the sample containing basaltic powder can be noticed. Fig. 4 depicts the main mineral phases identified: quartz [31] for both mixtures, and albite related to basaltic rocks for the mixture containing waste powder [32]. Fig. 5 shows similar pore size distribution for both mixtures, and total open porosity values of $31.65 \%$ and 

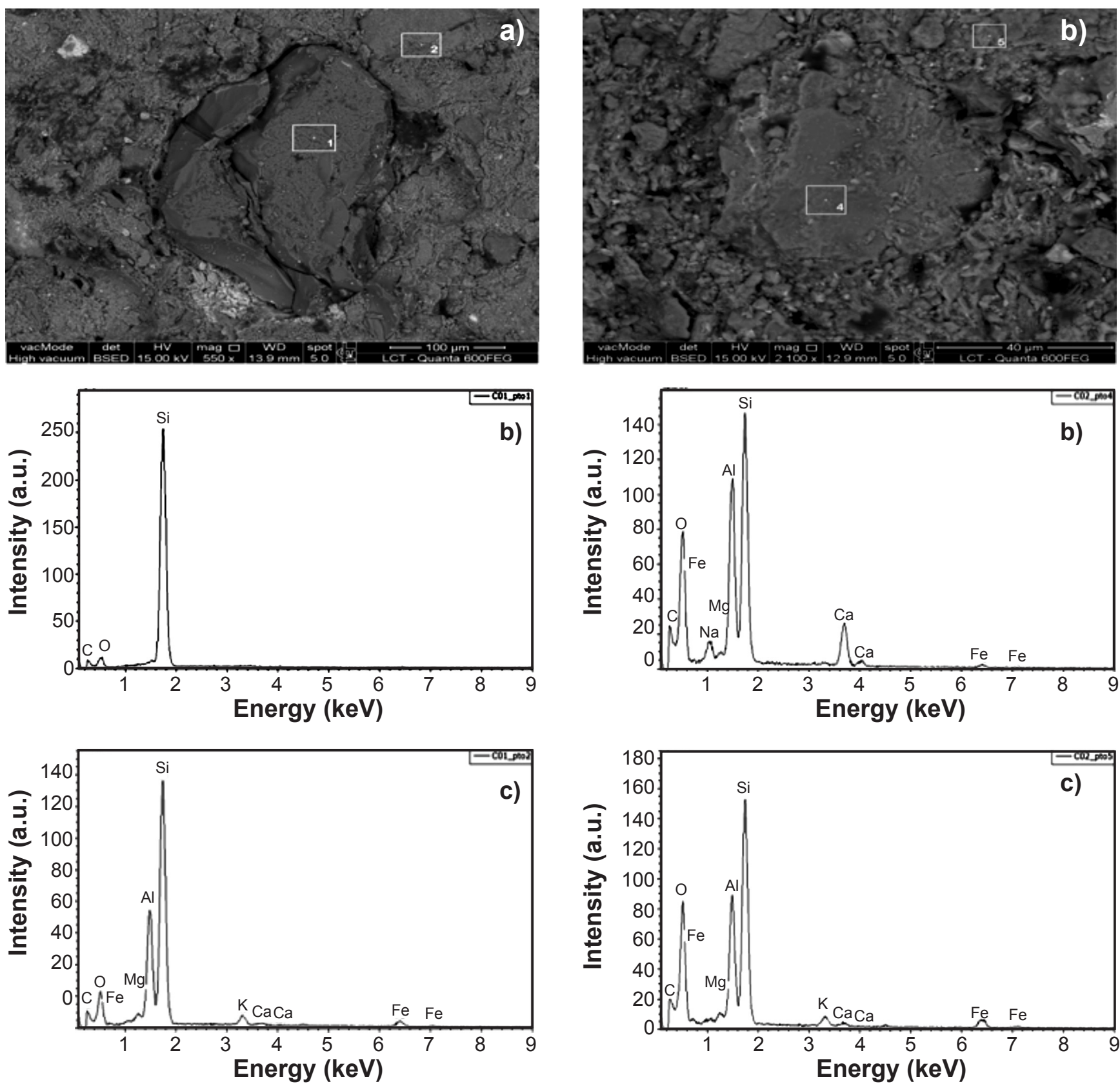

Figure 6: SEM micrograph of reference mixture (a), and EDS spectra of region 1 (b) and 2 (c).

[Figura 6: Micrografia de MEV da mistura de referência (a) e espectros de EDS da região 1 (b) e 2 (c).]

$30.46 \%$ for reference and $\mathrm{C} 02$ mixture, respectively.

Figs. 6a and 7a present the sample's micrograph of studied mixtures, obtained by scanning electron microscopy (SEM), and the delimitation of the analyzed region in order to identify the particles' chemical composition by energy dispersive spectroscopy (EDS). In Fig. 6a, it is possible to observe coarse quartz particles dispersed into a ceramic matrix. Figs. $6 \mathrm{~b}$ and $6 \mathrm{c}$ present the obtained EDS spectra, which show the Si predominant peak of quartz phase, and $\mathrm{Al}, \mathrm{Fe}, \mathrm{Ca}$ and $\mathrm{Mg}$ peaks present on ceramic matrix (Table II). Fig. 7a shows coarse particles from basaltic powder

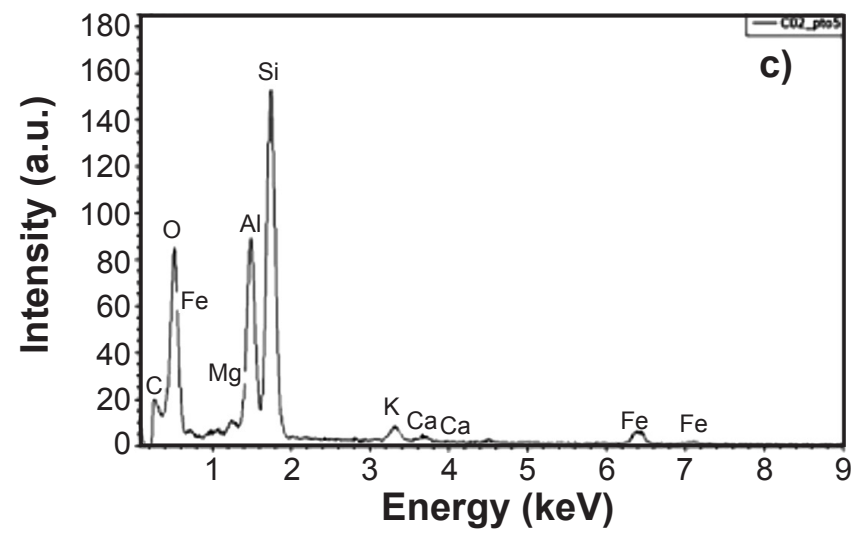

Figure 7: SEM micrograph of mixture C02 (a), and EDS spectra of region 4 (b) and 5 (c).

[Figura 7: Micrografia obtida por microscopia eletrônica de varredura da mistura C02 (a) e espectros de EDS da região 4 (b) e 5 (c).]

dispersed into a ceramic matrix. Figs. $7 \mathrm{~b}$ and $7 \mathrm{c}$ present the obtained EDS spectra, which show a different Na peak for coarse particle, mainly related to the presence of sodium in albite phase.

\section{CONCLUSIONS}

Basaltic powder reduces ceramic mass plasticity resulting in a linear relationship that could be used as parameter for extrusion. Basaltic chemical composition increases the total fluxing oxides and reduces refractory oxide content, but 
fluxing ions such as $\mathrm{Fe}, \mathrm{Mg}$ and $\mathrm{Ca}$ are chemically bonded in minerals such as albite and augite. For firing temperature studied $\left(850^{\circ} \mathrm{C}\right)$, these oxides do not act as fluxing promoter, so basaltic residue acts as inert filler. Residue does not change materials behavior during processing, maintaining the drying and firing shrinkage values constant. Ceramic body's properties, such as density, water absorption and mechanical performance, are not significantly affected by use of basaltic powder as raw material. Basaltic powder waste does not change the pore size distribution and total open porosity of ceramic formulations. Albite phase was identified for mixtures containing basaltic waste. Similar microstructure of coarse particles dispersed into a ceramic matrix was observed for both reference and basalticcontaining mixtures.

\section{ACKNOWLEDGEMENTS}

To Fundação Araucária de Apoio Desenvolvimento Científico e Tecnológico do Paraná; CAPES - Coordenação de Aperfeiçoamento de Pessoal do Ensino Superior; Laboratório de Caracterização Tecnológica da Escola Politécnica da Universidade de São Paulo LCT/USP; Laboratório de Física Nuclear Aplicada da Universidade Estadual de Londrina UEL.

\section{REFERENCES}

[1] A. I. National Association of Ceramic Industry, "www. anicer.com.br," 2008. [Online]. Available: http://www. anicer.com.br/index $. a s p ? p g=$ institucional. asp $\&$ secao $=3 \&$ ca tegoria $=60 \&$ selMenu $=4$.

[2] O. Montedo, G. Reitz, F. Bertan, R. Picolli, D.O.A. Hotza, Cerâm. Ind. 8 (2003) 14-17.

[3] V. Balaton, P. Gonçalves, L. Ferrer, Cerâm. Ind. 7 (2002) 42-45.

[4] M. Costa, M.L.J. Ribeiro, J.A. Labrincha, Cerâm. Ind. 7 (2002) 44-50.

[5] S. Monteiro, L. Peçanha, C. Vieira, J. Eur. Ceram. Soc. 24 (2004) 2349-2356.

[6] R. Menezes, H. Ferreira, G. Neves, H. Lira, H. Ferreira, J. Eur. Ceram. Soc. 25 (2005) 1149-1158.

[7] P. Torres, H. Fernades, S. Agathopoulos, D. Tulyagonov, J. Ferreira, J. Eur. Ceram. Soc. 24 (2004) 3177-3185.

[8] P. Torres, H. Fernandes, S. Olhero, J. Ferreira, J. Eur. Ceram. Soc. 29 (2009) 23-30.

[9] C. Viera, T. Soares, S. Monteiro, Cerâm. Ind. 9, 1 (2004) 28-32.

[10] C. Vieira, T. Soares, R. Sanchéz, S. Monteiro, Mate. Sci. Eng. A 373 (2004) 115-121.

[11] W. Acchar, F. Vieira, D. Hotza, Mater. Sci. Eng. A 419 (2006) 306-309.

[12] A.M. Sedagães, M. Carvalho, W. Acchar, Appl. Clay Sci. 30 (2005) 42-52.

[13] W. Acchar, F.A. Vieira, A.M. Segadães, Mater Sci. Eng. A 435 (2006) 606-610.
[14] C.M.F. Vieira, J. Emiliano, Cerâmica 59 (2013) 389394.

[15] C.M.F. Vieira, R.M. Pinheiro, Cerâmica 59 (2013) 495 500.

[16] E.E. Hekal, S. Abo-El-Enein, S. El-Korashy, G. Megahed, T. El-Sayed, J. Therm. Anal. Calorim. 613, 114 (2013) 613-619.

[17] K. Kim, S. Park, Y. Kim, Construction Buil. Mater. 40 (2013) 746-752.

[18] S. Teng, T. Lim, B. Divsholi, Construction Buil. Mater. 40 (2013) 875-881.

[19] K. Sho, S. Park, Y. Kim, G. Lee, K. Kim, Construction Buil. Mater. 25, 5 (2011) 2318-2322.

[20] L. Laibao, Z. Yunsheng, Z. Wenhua, Z. Lihua, Construction Buil. Mater. 48 (2013) 434-440.

[21] M. Hassan, Mater. Lett. 50, 2 (2001) 172-178.

[22] F. Andrade, Cerâmica 56 (2010) 39-43.

[23] C. Yen, D. Tseng, T. Lin, Chemosphere 84 (2011) 220226.

[24] N. Jain, Construction Buil. Mater. 27, 1 (2012) 39-44.

[25] M. Uysal, M. Sumer, Construction Buil. Mater 25 (2011) 4112-4120.

[26] H. Aruntas, M. Gurü, M. Dayi, I. Tekin, Mater. Design 31 (2010) 4039-4042.

[27] ABNT - Associação Brasileira de Normas Técnicas, "Determinação da Análise Granulométrica dos solos", NBR 7181 (1984) 1-13.

[28] ABNT - Associação Brasileira de Normas Técnicas, "Agregados - Determinação da massa específica de agregados miúdos por meio do frasco chapman - Método de ensaio", NBR 9776 (1987) 1-3.

[29] M.S. Hebmann, H.P.T. Coelho, A.R. SAlvetti. Anais do $45^{\circ}$ Congresso Brasileiro de Cerâmica, Florianópolis, S.C., Maio de 2001, disponível em https://www.ipen.br/ biblioteca/cd/cbc/2001/artigos/4-019.doc

[30] ASTM - American Society for Testing Materials, "Water Absorption, Bulk Density, Apparent Porosity, and Specific Gravity of Fired Whiteware Products", C373 (1972) 1-4.

[31] ASTM - American Society for Testing and Materials, "Flexural Properties of Ceramic Whiteware Materials", C674 (1984) 1-4.

[32] ASTM - American Society for Testing and Materials, "Standard Test Method for Dynamic Young's Modulus, Shear Modulus, and Poisson's Ratio by Impulse Excitation of Vibration", E1876 (2009) 1-16.

[33] Museu de Minerais e Rochas "Heinz Ebert", Universidade Estadual Paulista, UNESP, Disponível em http://www.rc.unesp.br/museudpm/rochas/

[34] V.V. Almeida, M.H.B.M. Hollanda, Rev. Bras. Geociências 39, 3 (2009) 580-598.

[35] F.G. Rosa, M.V. Folgueras, A.L. Longo, A. Cechenel,

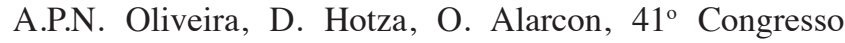
Brasileiro de Cerâmica, Florianópolis, S.C., Junho de 1999. Disponível em https://www.ipen.br/biblioteca/cd/cbc/1999/ Artigos/096.doc.

(Rec. 20/07/2015, Rev. 01/12/2015, Ac. 17/12/2015) 